\title{
WHAT FACTORS INCREASE THE IMPACT OF THE SAO'S AUDIT ACTIVITY AND THE AMOUNT OF AUDITED EXPENDITURES WITHIN THE MANDATE OF THE SAI?
}

\author{
Jan Buček ${ }^{1}$ \\ ${ }^{1}$ Department of Public Finance, Faculty of Finance and Accounting, University of Economics, Prague, \\ nám. Winstona Churchilla 1938/4, 13067 Praha 3-Žižkov, Czech Republic
}

Link to this article: https://doi.org/10.11118/actaun.2021.052

Received: 17. 5. 2020, Accepted: 6. 10. 2021

To cite this article: BUČEK JAN. 2021. What Factors Increase the Impact of the SAO's Audit Activity and the Amount of Audited Expenditures Within the Mandate of the SAI? Acta Universitatis Agriculturae et Silviculturae Mendelianae Brunensis, 69(5): 579-594.

\begin{abstract}
This study within the Czech Supreme Audit Office found that a relatively greater media impact had audits of the Czech Supreme Audit Office in which a criminal notification was filed. It was further found that notifications to the tax authorities were relatively more frequent for audits that focused on a longer period of time and that proportion of audit reports referring to Act No. 563/1991 Coll., Act on Accounting, is decreasing. The analysis of the Czech Supreme Audit Office also revealed that the audits for which the government imposed a remedial measure were not more expensive than those for which no government remedies were imposed. The author recommends the Czech Supreme Audit Office to continue to step up its efforts to reduce audits of formal deficiencies and to establish an independent advisory body for the evaluation of objections to audit protocols. Both content analysis and regression analysis were used as scientific methods here. The regression models were focused on variables increasing the amount of audited expenditure under the mandate of 115 Supreme Audit Institutions.
\end{abstract}

Keywords: SAI, SAO, audit action, audit report, impact of audit activity, impact of audit activity on media

\section{INTRODUCTION}

Issues of the Supreme Audit Institutions (hereinafter also referred to as "SAI"), both their legal anchoring and their activity within the system and impact on the system, are nowadays dealt with by a number of expert works, both foreign and domestic. Although several expert papers have already dealt with the impact of SAI activities in the broader sense of the word, there is still plenty of scope for further investigation, particularly with regard to the impact of activity of the Czech Supreme Audit Office (hereinafter also referred to as "SAO"). In this respect, expert literature indicates as one of the possible forms of impact of SAI activities also the impact on the media. However, with regard to the
Czech SAO, this impact has not yet been analysed by any study. The first aim of this work with regard to the impact of the Czech SAO activities on the media is to confirm or refute the three following hypotheses. The first hypothesis is that a relatively disproportionately larger amount of media reactions were related to audits in which a criminal notification was filed. The second hypothesis is that the audits for which the government imposed remedial actions had a relatively greater impact than the audits for which the government only took note the given findings. And the last hypothesis in the connection with impact of Czech SAO's activities on the media is that none of the media reported during the period under review more audits than the Czech News Agency (hereinafter also referred to 
as "CNA"). The second goal of the work is to examine the audit actions initiated by the Czech SAO during the period 2010-2015 to establish possible relations between the individual factors. To a limited extent, selected audit actions of the Czech SAO were already reviewed by Buček (2019) with the aim to ascertain any possible impact of the members charged with conducting the audit work. However, the examination is newly extended to all audits within the period under review and some other factors are also analysed.

The first hypothesis under the second objective of the paper is that for more than $80 \%$ of the years in the period under review, notifications to the tax authority were relatively more frequent for audits that on average focused on a longer period of time. The second hypothesis is that the proportion of audit reports referring to Act No. 563/1991 Coll. (i.e. Act on Accounting) during the period under review decreases. This hypothesis is based on the assumption that a greater focus of audits on performance indicators generally results in less need for a focus on formal, i.e. for example accounting deficiencies. The third hypothesis proposes that over a given period, there will be a high relative frequency of appeals against decisions on objections to audit protocols. Considered as high is the value of presence of appeals in more than $20 \%$ of the cases throughout the period under review. For the period from 2010, annual budgets of the Czech SAO, resp. actual expenditure incurred by the Czech SAO, were further considered. The fourth hypothesis in this regard was that the audits for which the government had imposed remedial measures were, on average, more costly than those for which the government had imposed no measures and only took note of the findings. There is a simplifying assumption that each audit with the same number of audited entities consumes the same amount of human resources. The last hypothesis under the second objective of the paper is that it will be established that differences between the members who conduct audit actions and drafting the audit conclusions ${ }^{1}$ are substantial with regard to the success of the audit conclusions. Specifically, the hypothesis here is that there will be a relative difference of more than $20 \%$ between the most and least successful member due regarding the number of corrective actions imposed by the government and the notifications filed as a result of the audit conclusion s/he creates. The third objective of this paper is to develop regression models to demonstrate the relationship between the amount of audited expenditure under the mandate of Supreme Audit Institutions and the selected independent variables, where the hypothesis of their assumed impact is that the variables increase the amount of audited expenditure.

\section{Literature Review}

The role and impact of SAI's activities has been in the past addressed in several expert works, also with regard to the comparison of selected SAIs (e.g. Pollitt and Summa 1997 or Pollitt et al. 1999 and Pollitt 2003) with an emphasis on performance reporting, but also on the methods to assess the financial impact of these audits, where authors (e.g. Lonsdale, 1999, 2000) have identified possible ways of evaluating SAI activities. Further examples of the procedures and resources adopted by the authors to measure the impact of SAIs can be found, for example, in Groenendijk (2004) and González et al. (2008). The lack of empirical evidence of audit impacts and hence the need to investigate these impacts in the field of performance audits is mentioned e.g. in the work of Norwegian authors focusing on the local SAI (Reichborn-Kjennerud and Johnsen, 2015). This work analyses data from a survey of auditees examining their stance towards making changes as a result of the SAI's audit work. The impact of the SAI in the area of government administration of the four Nordic countries is also the focus of a more recent work by the authors from 2019 (Reichborn-Kjennerud et al., 2019). Using regression analysis, this work shows that performance audits have a positive impact on the selected parameters. The consequences of media attention were also important factors.

In the work on measuring the output of SAI activities (Bonollo, 2019), the author concludes that research in this area has focused mainly on performance audits, but significantly less so on financial audits. Based on a review of the existing literature, the author also concludes that the authors rarely used quantitative indicators, but rather relied only on descriptive indicators. The author in turn recommends in her work introducing follow-up procedures to monitor the impact of SAI audit recommendations. Some recent works (e.g. Tudor-Tiron and Moldovan-Romain, 2019) address the relationship of performance audit to the selected indicators, such as corruption control, regulatory quality and others. Further may also be brought an example of the work on the significance of audited entities in relation to the frequency of audits. In particular, the authors (Adi and Dutil, 2018) examined whether the frequency and intensity of audits correspond to the financial significance of the ministries, which fall together with the provincial government and agencies under its responsibility. In their work they came to the conclusion that while some important ministries were constantly "under-audited" in the period under review, others suffered from "over-auditing", also due to their importance. The

1 The result of each audit action is an audit report that contains a summary of the facts identified during the audit. 
impact of audit processes on the implementation of recommendations was addressed by the work focusing on SAIs in Belgium and the neighbouring Netherlands (van Acker and Bouckaert, 2018). It concluded that political factors had a relatively greater impact on the implementation of the recommendations.

As reported in further work (ReichbornKjennerud et al., 2018), since the 1970s SAIs have expanded the role of external auditors of public administration. From mere observance that audited matters are in line with established norms they have assumed the role of assessors expressing opinions whether public administration operates on the basis of the so-called "3E" (economy, efficiency, effectiveness) or not. As a result, this research hints at the fact that the effectiveness of the audit depends on the extent to which the actual changes are being made, respectively, on learning from the results of past audits and their recommendations. In this work, there were analysed data on the responses of civil servants, namely 696 replies to questionnaires sent to 4 countries. The fact that the SAIs have the power to determine whether the authorities in question are 'working', respectively functioning as they should and fulfil their obligations, means that SAIs are often considered not only as guardians of transparency, but also of good public sector performance (Svärdsten, 2019). It may also be noted that public sector audit literature is outside the North European and Anglo-American contexts rather limited (Johnsen, 2019), particularly in the case of Africa, Asia and Latin America. The author (Johnsen, 2019) also notes that there are also large differences in the impact of audit institutions on organisations and a society. He also argues that, overall, auditors are less active in the fight against corruption. Moreover, within recent research he points out that independence and relevance of auditors are a persistent challenge.

However, examples of works focusing on Latin America can be found. Moreover, one such example (Yetano, Torres and Castillejos-Suastegui, 2019) on the basis of a questionnaire sent to a selected sample of entities that were evaluated on the basis of performance audits has arrived at a quite interesting result. This is a finding that those audited entities which consider performance audits as useful and trust the SAI's activities are at the same time also those that implement multiple recommendations and implement them earlier. Another example, this time focusing on Asia, is the research (Mir, Fan and Maclean, 2017) which using China's example finds that strengthening accountability for management in non-democratic jurisdictions through public sector auditing may represent a significant contribution. Relatively often examined issue is the link between the SAI and fight against corruption. The role of the SAI in fight against corruption has also been addressed in recent work comparing the selected SAIs from Scandinavia, Southern Europe and Africa (Reichborn-Kjennerud et al., 2019). The aim was to compare how these SAIs perceive their role in fight against corruption. The authors in their work show that the way SAIs organise their work cannot be simply explained by the level of corruption in individual countries. However, knowing to what extent the public organisations achieved their performance goals seems perfectly justified. Ascertaining the state of affairs is of considerable importance not only for citizens on the practical level, but also for the health and vitality of democratic governance (Pollitt, 1999).

Some interesting findings brings also the work from 2018 (Cordery and Hay, 2018), which, based on the performed analysis, finds that SAIs fail to discuss the negative consequences of their work. Relatively non-traditional research in the area of SAIs was in turn carried out by researchers using the example of the Finnish SAI (Ahonen and Koljonen, 2020). They sought to provide a qualitative, computation-assisted examination of prominent content patterns in order to investigate the changes in these patterns in reports focused on the performance audit of the Finnish SAI during the period 2001-2016. They found that effectiveness audit stands out in the patterns, while the efficiency audit is much weaker. The key issues of audit in public administration, including issues involving SAIs in the Czech Republic and Slovakia, were dealt with by several Czech and Slovak authors already in 2010 (Nemec et al., 2010). However, other studies by domestic authors can also be found in which descriptive statistics, simple statistical surveys or standardised examples were applied in some form. As an example of such work may serve the study focused on the scope of SAI audits in Slovakia and within the Visegrad group ${ }^{2}$ (Stašová, 2019). The study compared the number of audited entities and the number of auditors between 2014 and 2016, assessing their workload (the number of audited entities per auditor). The result of this work was, among other things, the finding that, in the Czech Republic there was the lowest number of audited entities per one auditor.

Issues related to SAIs are included also in the research by the Open Budget Survey. This offers the opportunity to test hypotheses on the impact of not solely economic variables on the volume of audited expenditures. According to some studies (e.g. Seifert, Carlitz and Mondo, 2013), over the time Open Budget Index (hereinafter also referred to as "OBI") provides objective data on transparency related to the countries' budgetary procedures. This

2 The Visegrad group includes the Czech Republic, Slovakia, Hungary and Poland. 
independent process guarantees reliability of the data presented, with the indicator values ranging from 0 to 100, where 100 is the maximum fiscal transparency and zero represents complete fiscal opacity. With respect to OBI, this work in turn comes up with a detailed explanation of how this index is constructed. The results of this survey thus suggest to be linked with the SAI-related issues. The Open Budget Survey was drafted by the International Budget Partnership in 2006, when the 2008 survey has already revealed a regrettable state of budget transparency in many world countries. The data from this survey have been used across time; for example already the 2010 survey results, which at that time covered 94 countries, have been used by some authors in their work (e.g. Renzio and Masud, 2011). For example, these authors found that countries with lower incomes, weaker democratic institutions and higher dependency on foreign aid and hydrocarbon sales tend to be less transparent. Thus, according to the authors, OBI helps to identify simple steps that governments and partakers in the countries concerned could take to improve the budget transparency.

With regard to further research, it may be mentioned that the disclosure of data on democracy, human capital and budgetary documents is related to the transparency, accountability and public engagement of the SAI (Harrison and Sayogo, 2014). Here, GDP was negatively linked to the specific transparency and accountability measures. However, the aim to establish the link between the OBI and another indicator has already been pursued by substantially more studies. Another example could be the research by Czech authors (Sedmihradská and Haas, 2012) showing no significant negative relationship between the budgetary transparency measured by the OBI and the budget deficit or public debt. Also mentioned may be studies focusing notably on the relationship between the OBI and human development, measured by the Human Development Index (Fukuda-Parr, Guyer and Lawson-Remer, 2013).

However, probably the most important work with regard to the interconnection of the $\mathrm{OBI}$ and SAI is the work of authors dealing with the economic impact of SAIs. According to these authors (Blume and Voigt, 2011), this is the first study to assess the economic impact of differences in SAI organisational arrangements on a cross-country basis. This study estimates the impact on several groups of selected economic variables, namely fiscal policy, government efficiency and corruption and productivity. Here, the authors found that, based on the countries surveyed, differences in independence, mandate, implementation records, or SAI organisational model seem to have no clear impact on any of the three groups of dependent variables. The only exception in this respect was the perception of the level of corruption, where this was significantly higher if the SAI was structured according to the judicial audit model. According to the results of a study that follows and deepens the above research (Gherai, Tara and Matica, 2016), the existence of SAI affects the perceived level of corruption and government efficiency; however, the study recognises the shortcomings of "mere existence" and therefore seeks to include also other factors related to the SAI's activity itself. It sets out the hypothesis that the larger the work of the SAI, the more it contributes to reducing corruption. Including other factors, it appears that the more extensive the SAI's work, the more it contributes to reducing corruption.

Further studies adopting the OBI data (Ríos, Bastida and Benito, 2014) found, among other things, that the legal system, political competition and economic level also affect budget transparency. This work examined the determinants of the legislative budgetary process, such as e.g. SAI budgetary surveillance or the economic level. Studies can also be found (Ramkumar, 2009) which, in the context of the global OBI results of 2008, also make recommendations to the SAIs for greater transparency, i.e. that SAIs could share budget and audit information with civil society groups and the wider public by issuing budget documents on budget and audit or through dissemination using the media. The results of other authors (Zuccolotto and Teixeira, 2014) have shown, inter alia, that countries, in which legislators and SAIs have more constitutional interdependencies, have greater budgetary transparency. In this sense, other authors (Brusca, Rossi and Aversano, 2016) have examined whether transparency, the quality of budgetary management and the strength of audit institutions have a positive impact on corruption and whether they can increase confidence in the government. Although the results pointed out that transparency, the quality of budgetary management or audit systems have a positive impact on the perception of corruption, it has not been shown that transparency or strengthening of the SAI has increased the level of confidence. In addition, the authors of another study with respect to developing countries (Zyl, Ramkumar and Renzio, 2009) state that monitoring the overall economy, efficiency, and effectiveness of expenditure may be a problem for developing countries that would have a judicial or Napoleonic SAI model. Conversely, for countries with the Westminster audit model, the challenge lies in the implementation and follow-up of audit recommendations, since SAIs do not have the same legal power here as in the judicial model and thus rely on political pressure.

\section{MATERIALS AND METHODS}

Impact of audit work on the media was analysed on the basis of unsorted data provided by the Czech SAO. These data had to be sorted and further 
analysed according to the selected parameters and hypotheses. By the number of articles are understood also articles available on the Internet. When quantifying the cost of audits, in all the assumed cases there is envisaged a simplification in that audit actions conclude within the same year in which they started. The funds actually spent in the year when the audit actions started are thus assumed also for those audits that have a certain overlap to the following year. The cost was based on the assumption that decisive was the number of months of the audit duration multiplied by the number of audited entities. The cost of the audit did not include the time following its completion, when each group leader should resolve possible objections to the audit protocols from the audited entities, and when the member in charge of the audit action should prepare an audit report from audit protocols. Another form of the impact, related to the number of filed notifications with the tax authority and filed criminal notifications, was quantified on the basis of audit reports and subsequently verified in the register of audit actions. As in the previous work of the author (Buček, 2019), the primary adopted research method was the content analysis. In the context of the impact of SAI activities, however, this approach has previously been already used in other studies (e.g. Groenendijk, 2004 or González et al., 2008). All the results obtained relate to the end of 2019. This is mainly due to the fact that impacts of the given audit need to be evaluated only after some time, since audit findings may theoretically have impacts also several years following the actual execution of the given audit (related to the meetings of the government or committees of the Chamber of Deputies). Based on the author's previous experience, the chosen time interval should be fully sufficient to adequately assess the impact of the work of the Czech SAO. The second research method used in this work is the regression analysis, where the value obtained from the Open Budget Survey is explained as a dependent variable, namely the percentage of expenditures audited under the mandate of the Supreme Audit Institution. The explanatory, independent variables, i.e. the behaviour of the above-mentioned dependent variable, should explain both the economic and non-economic variables listed below (subchapter Source of data). Among certain shortcomings of the presented research is certainly the fact that examined are only audited expenditures, while SAIs also focus on the management of state property and some of them also on the fulfilment of state budget revenues. To validate the pre-established hypotheses, four linear regression models are estimated. The choice of the model was based on the need to design the best possible model for explaining the audited percentage of expenditure which would also meet assumptions of the adopted methodology. The quality of the model was assessed not only with regard to the statistical significance of the estimated parameters and the overall quality of the model (F-test, adjusted coefficient of determination), but also with respect to the assumptions of the linear regression. ${ }^{3}$

\section{Source of Data}

The sources for analysis of the links between the selected factors were, in particular, the published annual reports of the Czech SAO, relevant audit reports, website of the Control Committee of the Chamber of Deputies of the Parliament of the Czech Republic and individual resolutions of the Government of the Czech Republic. Impact assessment in terms of the number of corrective measures imposed was based on the electronic library for the general public (eKLEP information system), in which the government resolutions on individual selected audit actions were searched based on the audit action's number and the relevant period. The sources for the regression analyses were data from Open Budget Survey (specifically question No. 120 - necessary final consent (legislator or judge) before dismissing the head of SAI from office, question No. 102 - SAI/legislator provides a report to the public, question No. 97 - types of audits performed, question No. 121 - institution's budget - specification of who determines the institution's budget/level of funding needed to fulfil the mandate), World Bank (GDP - in current USD, GDP per capita in purchasing power parity - in current international USD, Final consumption expenditure of the general government - share of the general government expenditure in GDP, in \%, Government expenditure - share of the government expenditure in GDP, in \%, Government Effectiveness Index and Control of Corruption Indicator) and Transparency International Report (Corruption Perceptions Index). The 2017 Open Budget Survey covers in total 115 world countries. Therefore, a regression analysis is carried out both for the 115 world countries and separately for the 22 available OECD countries, when in the case of OECD countries, the author also attempts to integrate the variable of the government investment as \% of GDP (World Bank).

\section{RESULTS}

This section presents the results of all the audit work initiated by the Czech SAO during the period 2010-2015 and provides the analysis of the selected factors of all of the $200+$ Czech SAO audits that

3 These are the constant residue variance (White test) and the normal residue distribution. When the assumption of the constant residue variance was not met, a linear model corrected for heteroscedasticity was estimated instead. 
were carried out. The last subchapter contains econometric analysis and presents four prepared regression models: two major models for the world and OECD and two minor models for the world and OECD which additionally examine the extrabudgetary funds. The hypothesis is that all of the above-mentioned independent variables increase the amount of audited expenditure.

\section{Impact on the Media}

In the case of the media impact measured for audits which has started between 2010 and 2015, due to the small number of filed criminal notifications it is necessary to exclude both border years of our observation period, i.e. data for 2010 and 2015 are excluded from the further analysis. These two years are also characterised by extreme average values and as such would only distort the resulting calculations. As the remaining years in the period under review indicate, audits with at least one filed criminal notification have demonstrably greater media impact. The average of articles which reported on the outcome of the given audit was for the group of audits with filled criminal notifications higher by at least $44.59 \%$ (in 2012) and the differential value has reached its maximum of $185.95 \%$ in 2011 . In the case of the media impact, the government-imposed remedial measures do not have any effect. In just three of the six years under review there could be detected any larger media impact, specifically for audit actions with the government-imposed corrective measures. The largest relative and absolute differences were recorded for the audits which were initiated in 2014 when the average media impact was greater for audit actions with the government-imposed corrective measures (Tab. I).

The Tab. II shows on how many audits had the selected media reported in at least one article over the given year. MF DNES, Právo daily, Lidové noviny and Hospodářské noviny are among the most widely read daily papers in the Czech Republic, with the exception of tabloids and sports daily papers. The tabloid daily Blesk is the most frequently read newspaper in the Czech Republic. The results show that the most read tabloid medium mentions the Czech SAO audit actions considerably less than the media which might be labelled as reputable. However, this is not surprising given the nature of the tabloids and their focus. From the data below there may also be seen the time trend of a significant increase in the number of audits which results were media-reported to the general public. One can also notice another interesting fact. Between the years 2012 and 2014 reported on the Czech SAO audits much more frequently media which may be labelled as the centre-right and centre-left when compared to the media focused directly on politics and economics (Hospodářské noviny and iHNed.cz), and the largest reputable medium in the Czech Republic (MF DNES and iDNES.cz). The medium which has over the reviewed period reported on the largest number of audits at least one piece of news was the Czech News Agency (the results are not shown in the table but in the footnotes). In 2013 and 2014 CNA has reported on all Czech SAO audit actions and in the remaining years on at least $81 \%$ of all the audits that were carried out. ${ }^{8}$ When compared to the data in the table, this is absolutely the highest coverage.

In the Tab. III., for each followed medium there is calculated a hypothetical impact indicator (the first part of the table columns). This factor is based on readability of the printed content in each year and the number of audits that the media reported at least once. This indicator suggests that except for 2010, the overall hypothetical media impact of the Czech SAO audits within the reputable press

I: Audit actions of the SAO - Average media impact of an audit action - criminal notifications and the government-imposed corrective measures

\begin{tabular}{cccccccc}
\hline \multicolumn{2}{r}{ Period } & Without a notification With a notification & Difference & Without G.A. ${ }^{5}$ & With G.A. & Difference & Number of AC $^{6}$ \\
\hline 2010 & 24.07 & 286.50 & - & 40.60 & 41.08 & $+1.18 \%$ & 31 \\
2011 & 29.26 & 83.67 & $+185.95 \%$ & 36.00 & 33.03 & $-8.25 \%$ & 37 \\
2012 & 37.07 & 53.60 & $+44.59 \%$ & 38.17 & 39.69 & $+3.98 \%$ & 35 \\
2013 & 26.50 & 38.50 & $+45.28 \%$ & 33.00 & 26.94 & $-18.36 \%$ & 40 \\
2014 & 35.29 & 60.60 & $+71.72 \%$ & 30.80 & 42.94 & $+39.42 \%$ & 41 \\
2015 & 26.29 & 13.00 & - & 29.60 & 25.41 & $-14.16 \%$ & 39 \\
\hline
\end{tabular}

Source: Author, based on the information from $\mathrm{SAO}^{7}$

Difference between the average media impact.

Without government-imposed corrective measures.

Number of audit conclusions.

Information from the audit actions; audit reports; internal SAO monitoring of media response.

8 CNA (most audits) - 2010: 80.65\%, 2011: 91.89\%, 2012: 97.14\%, 2013, 2014: 100\%, 2015: 97.44\%. 
II: Audit actions of the SAO - Impact on the media - the number of audits reported by daily newspapers (at least one report)

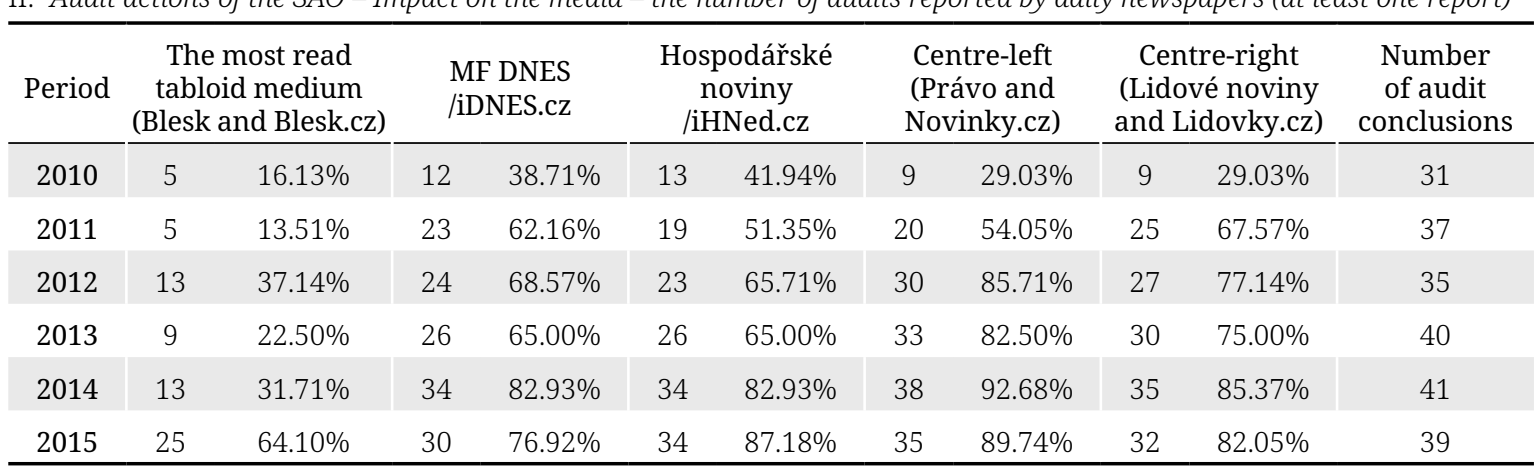

Source: Author, based on the information from SAO ${ }^{9}$

has not significantly changed through the years. Starting from 2011, an initial growth has always alternated with a subsequent decline. The impact of SAO's activities on the media is also important given the fact that there can be observed the impact of the media on a society, e.g. in shaping the public interest and a subsequent public debate on certain topics (Happer and Philo, 2013). The overall relative representation of the articles is shown in the second part of the table columns. Although CNA reported each year within the reviewed period on the most audits $^{10}$, the total number of articles in relative terms tends to rather decrease, which can be explained by the growing interest of other (and thus also different from the listed below) media.

\section{Factor Analysis}

As the Tab. IV shows, although it could be expected that the longer the audited period within the given audit, the more frequent should be the reports to the tax authorities, in 2010 this was not the case. However, in the remaining 5 years this is so and suggests that the audited period could be a significant also within a longer period of time. As the Tab. IV also shows, there is no clear relationship between the corrective measures imposed by the government and the number of audited entities: in two years, the number of audited entities was higher for audits without government-imposed corrective measures and in four years for audits with a government-imposed corrective action. In this respect, the period under review does not allow any generalisation of the conclusions that were reached. Further it shows, the number of audited entities does not have a clear link even with respect to the audit conclusions discussed in the committees (most often the Control Committee) of the Chamber of Deputies. In four years, the average number of audited entities was higher for audits not discussed in the committees of the Chamber of

III: Audit actions of the SAO - Impact on the media - the number of audits reported by the daily newspapers (at least one report) - approximation of the impact, share of individual articles on the SAO audits on all articles on the SAO audits (\%)

\begin{tabular}{|c|c|c|c|c|c|c|c|c|c|c|c|c|}
\hline \multirow{2}{*}{$\begin{array}{l}\text { Period } \\
2010\end{array}$} & \multicolumn{2}{|c|}{$\begin{array}{l}\text { Blesk, } \\
\text { impact indicator } \\
\text { (thous.) }\end{array}$} & \multicolumn{2}{|c|}{$\begin{array}{l}\text { MF DNES, } \\
\text { impact indicator } \\
\text { (thous.) }\end{array}$} & \multicolumn{2}{|c|}{$\begin{array}{l}\text { Hospodářské } \\
\text { noviny, } \\
\text { impact indicator } \\
\text { (thous.) }\end{array}$} & \multicolumn{2}{|c|}{$\begin{array}{l}\text { Právo, } \\
\text { impact indicator } \\
\text { (thous.) }\end{array}$} & \multicolumn{2}{|c|}{$\begin{array}{l}\text { Lidové noviny, } \\
\text { impact indicator } \\
\text { (thous.) }\end{array}$} & \multirow{2}{*}{$\begin{array}{c}\begin{array}{c}\text { Total } \\
\text { impact } \\
\text { (thous.) }\end{array} \\
814.78\end{array}$} & \multirow{2}{*}{$\begin{array}{r}\begin{array}{r}\text { Impact } \\
\text { without }\end{array} \\
\begin{array}{c}\text { Blesk } \\
\text { (thous.) }\end{array} \\
589.78\end{array}$} \\
\hline & 225 & 0.7 & 328 & 5.30 & 78 & 7.25 & 122 & 2.89 & 62 & 4.60 & & \\
\hline 2011 & 180 & 0.40 & 507 & 7.30 & 100 & 5.70 & 225 & 4.17 & 156 & 6.34 & $1,168.14$ & 987.73 \\
\hline 2012 & 454 & 1.52 & 551 & 6.23 & 127 & 4.71 & 323 & 4.42 & 161 & 5.72 & $1,616.77$ & $1,162.51$ \\
\hline 2013 & 260 & 0.99 & 518 & 5.69 & 116 & 5.69 & 275 & 6.23 & 14 & 6.59 & $1,313.44$ & $1,053.98$ \\
\hline 2014 & 351 & 2.47 & 577 & 7.12 & 144 & 6.00 & 312 & 5.82 & 167 & 5.06 & $1,551.29$ & $1,200.29$ \\
\hline 2015 & 649 & 3.36 & 489 & 5.63 & 135 & 7.02 & 269 & 5.83 & 168 & 5.24 & $1,709.75$ & $1,061.03$ \\
\hline
\end{tabular}

Source: Author, based on the information from $\mathrm{SAO}^{11}$ and Research of press readership ${ }^{12}$

9 Internal SAO monitoring of media response.

10 CNA (most audits) - share of individual articles on the SAO audits on all articles on the SAO audits (\%) 2010: 9.52, 2011: 9.39, 2012: 6.38, 2013: 6.86, 2014: 6.94, 2015: 5.43. The part with the overall relative representation of the articles includes MF DNES/iDNES.cz, Hospodářské noviny/iHNed.cz, Centre-left (Právo and Novinky.cz), Centre-right (Lidové noviny/Lidovky.cz).

11 Internal SAO monitoring of media response.

12 Research of press readership - Media Project, Union of Publishers and Association of Media Agencies, 2010-2015. 
IV: Audit actions of the SAO - audited period in years and reports to the tax authority (TA) (\%), the number of audited entities and the government-imposed measures

\begin{tabular}{|c|c|c|c|c|c|c|c|c|}
\hline Period & $\mathrm{AP}^{13}$ & $\begin{array}{l}\text { Reported } \\
\text { to the } \mathrm{TA}^{14}\end{array}$ & $\begin{array}{c}\text { No notification } \\
\text { to the } \mathrm{TA}^{15}\end{array}$ & Difference $^{16}$ & AE without $\mathrm{GA}^{17}$ & AE with $\mathrm{GA}^{18}$ & $\mathrm{AE}-\mathrm{CHD}^{19}$ & ${ }^{9} \mathrm{AE}-\mathrm{no} \mathrm{CHD}^{20}$ \\
\hline 2010 & 3.19 & 2.99 & 3.35 & -10.70 & 8.40 & 8.19 & 7.89 & 8.36 \\
\hline 2011 & 3.53 & 3.73 & 3.40 & +9.70 & 8.75 & 8.83 & 6.33 & 9.29 \\
\hline 2012 & 4.03 & 4.20 & 3.90 & +7.69 & 3.83 & 6.55 & 5.70 & 6.60 \\
\hline 2013 & 3.33 & 3.57 & 3.14 & +13.63 & 6.60 & 7.43 & 6.37 & 8.19 \\
\hline 2014 & 4.38 & 4.57 & 4.11 & +11.32 & 6.60 & 5.14 & 5.88 & 4.96 \\
\hline 2015 & 4.44 & 4.51 & 4.37 & +3.26 & 5.20 & 5.85 & 6.03 & 5.00 \\
\hline
\end{tabular}

Source: Author, based on the information from SAO and the Government ${ }^{21}$

Deputies, in two years in turn for audits discussed in the committees of the Chamber of Deputies.

As the Tab. $V$ below shows, efforts to focus audits on performance indicators have proven to be real in recent years. Audit conclusions are substantially less based on the Act on Accounting. Since 2011, there has been a clear trend where the focus of audits on performance indicators generally brings less need to focus on the formal, i.e. accounting side of the matters. With respect to the legislative regulations there was further found that the number of legislative rules present in the given audit conclusion is not related to whether or not a government remedial measure was imposed. During the period under review, in three of the years the average number of legal regulations was higher for audits with the government-imposed remedial action and in three years yet for audits without the government-imposed corrective measures.

The rate of appeals against settlements of objections to audit protocols is high throughout the entire period under review, when its lowest value reaches $36 \%$, as shown in the Tab. VI. In one of the years, the settlement of objections to audit protocols even resulted in appeals against settlements of objections in more than $50 \%$ of the cases. The rising number of appeals against settlements of objections in the second half of the period under review indicates a possible problem with regard to the correct decision on filed objections against audit protocols. Although

V: Audit actions of the SAO - the number of audit conclusions referring to Act No. 563/1991 Coll., the number of legal regulations applied per audit conclusion and remedial measures imposed by the government

\begin{tabular}{ccccc}
\hline Period & $\begin{array}{c}\text { Act on Accounting } \\
\text { (\% of audit conclusions) }\end{array}$ & $\begin{array}{c}\text { Average number of legislative } \\
\text { regulations used per } 1 \text { audit conclusion }\end{array}$ & Legislation $-\mathrm{GA}^{22}$ & Legislation $-\mathrm{no} \mathrm{GA}^{23}$ \\
\hline 2010 & 54.84 & 8.94 & 8.62 & 10.60 \\
2011 & 64.86 & 8.81 & 8.52 & 7.13 \\
2012 & 51.43 & 9.46 & 10.00 & 6.83 \\
2013 & 45.00 & 7.35 & 7.14 & 8.80 \\
2014 & 39.02 & 8.27 & 8.53 & 6.40 \\
\hline 2015 & 38.46 & 7.64 & 7.62 & 7.80 \\
\hline
\end{tabular}

Source: Author, based on the information from $\mathrm{SAO}^{24}$

13 Audited period in years - average.

14 Reported to the tax authority - average audited period in years.

15 No notification to the tax authority - average audited period in years.

16 Difference - by how many \% is the audited period longer when reporting to the tax authorities compared to not reporting to the tax authorities.

17 Average number of audited entities for audits without government-imposed corrective measures.

18 Average number of audited entities for audits with government-imposed corrective measures.

19 Average number of audited entities for audits discussed in the committees of the Chamber of Deputies.

20 Average number of audited entities for audits not discussed in the committees of the Chamber of Deputies.

21 Information from the audit actions; audit reports; Government - Information from the Government application ODok; section "Documents” of the website of the Chamber of Deputies' Control Committee.

22 Average number of legislation - government corrective action imposed.

23 Average number of legislation - no government remedial action.

24 Information from the audit actions; audit reports. 
appeals against settlements of objections within the period under review are more frequent for audits without the government-imposed corrective measures in 4 of the 6 reviewed years, the results over the reviewed period are not significant enough to allow for drawing some generalising conclusions. This would require a considerably longer period of time. The average expenditure per 1 audit without the government-imposed corrective measures was within the period under review in half of the cases higher and in half of the cases (years) lower. Thus, no significant relationship was found between the costliness of audits and their impact in the form of the government-imposed corrective measures, as shown in the Tab. VI below.
When excluding the Czech SAO members with potential numbers 15-19 who conducted during the period under review 5 or fewer audits, we find out that for each member, a certain amount of the audit conclusions that $\mathrm{s} /$ he drafted was discussed within the committees (most often the Control Committee) of the Chamber of Deputies. This amount ranges from $16.7 \%$ of the audit conclusions up to $75 \%$, as shown in the Tab. VII below. It further shows there are significant differences in how the members can draft an audit conclusion and what serious the findings in it are reported to the government. If we consider conclusions whose findings and recommendations led the government to impose on their basis a corrective measure, we talk about the range of $23.53 \%$ to $50 \%$. It is also interesting to note that the

VI: Audit actions of the SAO - appeals against the settlement of objections and the government-imposed remedial measures, actual SAO expenditures and the government-imposed measures

\begin{tabular}{ccccccc}
\hline Period $\begin{array}{c}\text { Appeal against } \\
\text { the settlement } \\
\text { of objections }{ }^{25}\end{array}$ & $\begin{array}{c}\text { Appeals } \\
- \text { no GA }^{26}\end{array}$ & $\begin{array}{c}\text { Appeals } \\
- \text { GA }^{27}\end{array}$ & $\begin{array}{c}\text { Total actual SAO } \\
\text { expenditures } \\
\text { (in CZK thousands) }\end{array}$ & $\begin{array}{c}\text { Expenditures per 1 } \\
\text { audit - no GA } \\
\text { (in CZK thousands) }\end{array}$ & $\begin{array}{c}\text { Expenditures } \\
\text { per 1 audit - GA } \\
\text { (in CZK thousands) })^{29}\end{array}$ \\
\hline 2010 & $40.63 \%$ & $60 \%$ & $46 \%$ & 542,596 & $17,807.56$ & $17,444.55$ \\
2011 & $37.33 \%$ & $75 \%$ & $35 \%$ & 501,356 & $14,231.79$ & $13,839.35$ \\
2012 & $36.11 \%$ & $33 \%$ & $45 \%$ & 468,619 & $8,042.77$ & $14,495.26$ \\
2013 & $47.46 \%$ & $60 \%$ & $51 \%$ & 463,881 & $10,989.33$ & $11,683.84$ \\
\hline 2014 & $57.14 \%$ & $40 \%$ & $56 \%$ & 435,441 & $11,847.93$ & $10,450.04$ \\
\hline 2015 & $45.31 \%$ & $60 \%$ & $56 \%$ & 472,925 & $10,126.98$ & $12,420.30$ \\
\hline
\end{tabular}

Source: Author, based on the information from SAO and Government ${ }^{30}$

VII: SAO members and the impact of audits they conducted during the period 2010-2015

\begin{tabular}{|c|c|c|c|c|c|c|c|c|}
\hline \multirow{2}{*}{$\begin{array}{l}\text { Member } \\
1,2\end{array}$} & \multicolumn{2}{|c|}{$\begin{array}{l}\text { Number of audits } \\
\text { for which was filed } \\
\text { at least one criminal } \\
\text { notification (\%) }\end{array}$} & \multicolumn{2}{|c|}{$\begin{array}{l}\text { Number of audits } \\
\text { reported to the tax } \\
\text { authorities (\%) }\end{array}$} & \multicolumn{2}{|c|}{$\begin{array}{c}\text { Number of audits } \\
\text { based on which } \\
\text { the government imposed } \\
\text { a corrective measure (\%) }\end{array}$} & \multicolumn{2}{|c|}{$\begin{array}{l}\text { Number of audits } \\
\text { discussed at the Chamber } \\
\text { of Deputies (\%) }\end{array}$} \\
\hline & 11.11 & 10.53 & 44.44 & 47.37 & 44.44 & 36.84 & 44.44 & 42.11 \\
\hline 3,4 & 30.00 & 7.14 & 40.00 & 21.49 & 50.00 & 42.86 & 30.00 & 64.29 \\
\hline 7,8 & 5.88 & 0.00 & 29.41 & 18.18 & 29.41 & 45.45 & 41.18 & 45.45 \\
\hline 9,10 & 12.50 & 0.00 & 75.00 & 30.77 & 25.00 & 38.46 & 37.50 & 46.15 \\
\hline 11,12 & 25.00 & 28.57 & 56.25 & 57.14 & 25.00 & 28.57 & 75.00 & 42.86 \\
\hline
\end{tabular}

Source: Author, based on the information from SAO and Government ${ }^{31}$

25 In how many \% the settlement of objections against audit protocols resulted in an appeal against the settlement of objections.

26 Frequency of appeals against settlements of objections for audits without government-imposed remedies.

27 Frequency of appeals against settlements of objections for audits with government-imposed remedial measures.

28 Average expenditures per 1 audit without the government-imposed measures (in CZK thousands).

29 Average expenditures per 1 audit with the government-imposed measures (in CZK thousands).

30 Information from the audit actions; audit reports; Government - Information from the Government application - ODok; Final accounts for the period 2010-2015 (Chapter 381), Supreme Audit Office.

31 Information from the audit actions; audit reports; Government - Information from the Government application ODok; section "Documents" of the website of the Chamber of Deputies' Control Committee. 
government has imposed most remedial measures on audits of the one member who in its audits has also filed the largest number of criminal notifications.

\section{Regression Analysis}

This subchapter presents the results of four constructed econometric models, which should demonstrate the impact of the selected variables on the amount of audited expenditures. The hypothesis for all the independent variables is that they increase the amount of audited expenditures under the SAI mandate. The models are constructed using such variables that allowed to explain the explanatory variable.

\section{Regression Model - the World}

Regression analysis on the sample of 115 world countries has revealed (Tab. VIII) that the audited percentage of expenditures under the SAI mandate, respectively, the explained variable, can be explained by the number of performed types of audit (Types of audits), the Control of Corruption Indicator (CCI), the Corruption Perception Index (CPI), government spending relative to GDP (G) and SAI's transparency (SAI/legislator provides the public with a follow-up on to the audit authority's corrective measures). All the explanatory variables included in the model are significant at the level of at least $10 \%$ of the statistical significance. Using the estimated model, it was possible to explain over $50 \%$ of variability of the examined variable.

\section{Regression Model - the World - Extra-budgetary Funds}

The most appropriate model for the percentage of expenditures related to 115 world extrabudgetary funds audited under the SAI mandate (Tab. IX) includes the following explanatory variables: number of performed types of audit (Types of audits), Control of Corruption Indicator (CCI), Government Effectiveness Index (GEI), the Corruption Perception Index (CPI), GDP and SAI's transparency. Similar to the previous regression model, transparency of SAIs scores a positive impact, albeit it remains statistically insignificant. However, its inclusion into the model contributes to improving its overall quality. ${ }^{32}$ This way, using the adopted repressors the model is able to explain 90\% of the variability of the dependent variable.

\section{Regression Model - OECD}

When the regression analysis focuses only on OECD member countries, the most appropriate model for determining the percentage of expenditures

VIII: Dependent variable: Audited percentage of expenditure under the SAI mandate

\begin{tabular}{lccccc}
\hline & Coefficient & std. error & t-test & p-value & \\
\hline Const & -25.6244 & 13.8799 & -1.846 & 0.0681 & $*$ \\
Types of audits & 0.519794 & 0.0949058 & 5.477 & $3.67 \mathrm{e}-07$ & $* * *$ \\
SAI's transparency & 0.246460 & 0.0907682 & 2.715 & 0.0079 & $* * *$ \\
CCI & -0.946454 & 0.464371 & -2.038 & 0.0444 & $* *$ \\
CPI & 1.50833 & 0.711030 & 2.121 & 0.0366 & $* *$ \\
G & 0.732973 & 0.400030 & 1.832 & 0.0701 & $*$ \\
\hline
\end{tabular}

Source: Author, based on the information from the Open Budget Survey, the World Bank, the Transparency International Report

IX: Dependent variable: Audited percentage of the extra-budgetary funds' expenditure under the SAI mandate

\begin{tabular}{|c|c|c|c|c|c|}
\hline & Coefficient & std. error & t-test & $\mathrm{p}$-value & \\
\hline Const & -25.2124 & 5.48076 & -4.600 & $1.18 \mathrm{e}-05$ & $* * *$ \\
\hline Types of audits & 0.679116 & 0.0552431 & 12.29 & $4.69 e-022$ & $* * *$ \\
\hline SAI's transparency & 0.0493676 & 0.0685172 & 0.7205 & 0.4728 & \\
\hline $\mathrm{CCI}$ & -0.575626 & 0.209322 & -2.750 & 0.0070 & $* * *$ \\
\hline GEI & -0.237565 & 0.118152 & -2.011 & 0.0469 & $* *$ \\
\hline CPI & 1.50174 & 0.376534 & 3.988 & 0.0001 & $* * *$ \\
\hline GDP & $1.09383 \mathrm{e}-06$ & 7.97588e-07 & 1.371 & 0.1732 & \\
\hline
\end{tabular}

Source: Author, based on the information from the Open Budget Survey, the World Bank, the Transparency International Report

32 Inclusion of the variable describing transparency of SAIs has contributed both to fulfilment of the assumptions of linear regression and overall better explanatory quality of the model. 
X: Dependent variable: Audited percentage of expenditure under the SAI mandate

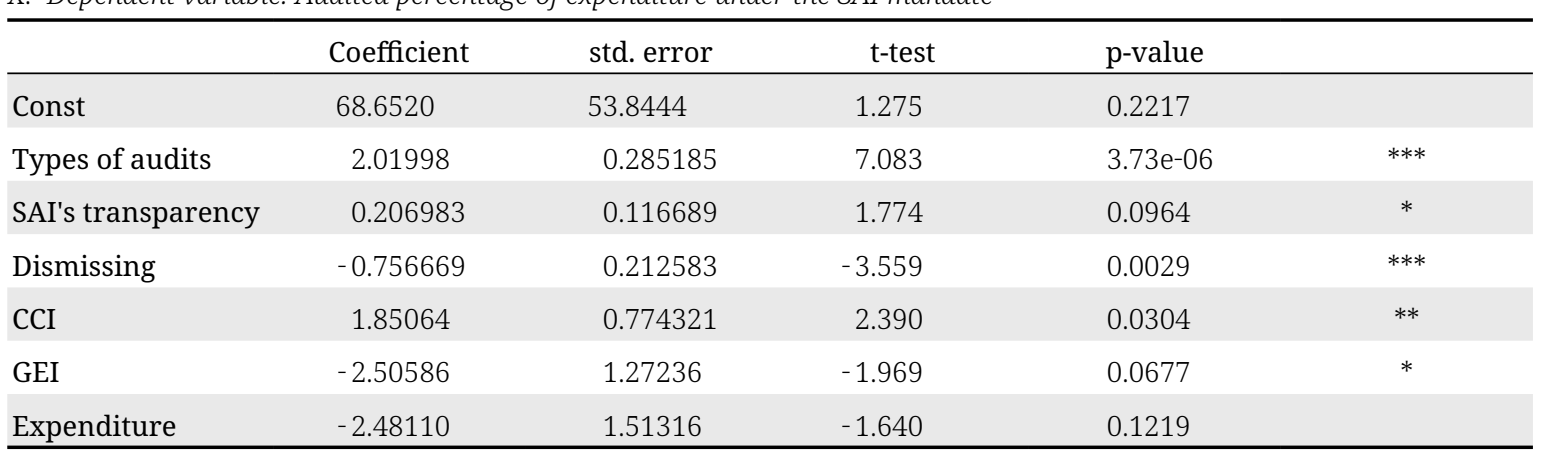

Source: Author, based on the information from the Open Budget Survey, the World Bank, the Transparency International Report

XI: Dependent variable: Audited percentage of the extra-budgetary funds' expenditures under the SAI mandate

\begin{tabular}{lcccc}
\hline & Coefficient & std. error & t-test & p-value \\
\hline Const & -16.4731 & 47.4628 & -0.3471 & 0.7331 \\
Types of Audits & 1.77503 & 0.289432 & 6.133 & $1.44 \mathrm{e}-05$ \\
Dismissing & -0.601083 & 0.217450 & -2.764 & 0.0138 \\
CCI & 1.90916 & 0.663639 & 2.877 & 0.0110 \\
Expenditure & -2.43707 & 1.53412 & -1.589 & 0.1317 \\
GEI & -1.38460 & 1.04681 & -1.323 & 0.2045
\end{tabular}

Source: Author, based on the information from Open Budget Survey, the World Bank, the Transparency

audited under the SAI mandate (Tab. X) includes the following variables: the number of performed types of audit (Types of audits), SAI's transparency, the Control of Corruption Indicator (CCI), Government Effectiveness Index (GEI), and the way of dismissing the head of SAI from office (Dismissing). The given explanatory variables are significant at least at 10\% of the statistical significance level. Beyond these variables, the model also includes expenditure of the general government on its final consumption (relative to GDP), since based on information criteria it improves the overall quality of the model $^{33}$. The model is thus able to explain about $80 \%$ of the variability of the audited percentage of expenditure.

\section{Regression Model - OECD - Extra-budgetary Funds}

In the case of audited percentage of the extrabudgetary funds' expenditures, the resulting regression model is similar to the previous analysis. The model (Tab. XI) contains the same explanatory variables, except for the SAI's transparency variable, the use of which is in this case not beneficial. Also the qualitative effect of the variables on the share of audited expenditures is the same as for the budget expenditure of OECD countries. Thus, the hypothesis is again confirmed for the types of audit where the p-value reaches $1.44 \mathrm{e}-05$ and for the Control of Corruption Indicator, where the p-value is 0.0110 . The model includes two variables (government final consumption expenditure relative to GDP and Government Effectiveness Index) that although not statistically significant at common levels, they do not fall too far away and their inclusion allows for a better estimate of the audited percentage of expenditure. As a result, the model manages to explain three quarters of the variability of the dependent variable.

\section{DISCUSSION}

The author focused mainly on the governmentimposed corrective measures with regard to the most common available instruments of measuring the impact of SAIs activities (e.g. Pollit, 1999). However, here the author has already not examined whether as a result of this measure there came to any legislative change or not. On the other hand, the work of Buček (2019) has already focused on the legislative aspects within the narrower audit area where a more focused section of audit work allowed for the examination and quantification of legislative impacts. Within the factor analysis, the

33 Omission of the final government consumption led to a deterioration of all the assumed information criteria. Evaluated were Akaike, Schwarz and Hannan-Quinn criterions. 
high level of appeals against decisions on objections to audit protocols gives some indication that the existing system may not be set up optimally. This is due to the fact that, based on the obtained results, the heads of the auditing groups find it difficult to handle the settlement of objections to audit reports submitted by audited entities. ${ }^{34}$ Although more of a political decision, in this case it would make sense to set up an independent body that would have a truly independent say on the objections raised by the audited entities. Positive is another uncovered fact. That is, due to the decreasing use of the Act on Accounting in audit reports, the Czech SAO appears to be largely trying to reorient the focus of its audits from evaluating only formal aspects, most often accounting errors, to performance indicators, respectively, performance audits focused on the socalled "3E" (economy, efficiency, effectiveness). The need for these steps was already discussed in 2010 by some Czech and Slovak authors (Nemec et al., 2010).

As it has also been shown by the impact of more than 200 audit reports for audit actions launched between 2010 and 2015, there are significant differences between the members who draft the audit reports. This research was a follow-up to the author's previous research (Buček, 2019), which assessed audits focused on specific audit areas, where one of the factors was also the members' work. A significant impact on the fact whether the government has imposed corrective measures on the basis of an audit report or merely took note the findings of the audit report may also have the way how the member formulates the findings contained in the audit protocols, respectively, how s/he manages the entire audit action. A question also remains what actual impact has the fact that the members of the Czech SAO are not assigned individual audit actions according to their expertise in contrast to the praxis e.g. at the European Court of Auditors, where new members are assigned to specialised senates and audit groups. As a result, e.g. a newly appointed Czech SAO member can prepare audit reports on tax issues, although s/he has never oriented or been professionally active in the tax domain before. The author has found as interesting the fact that it has not been established that audits with the government-imposed corrective measures are more costly than audits where the government only took note of the findings. Although the hypothesis that audits with the government-imposed measures were more costly was not based on any unrealistic assumption, as the author assumed that with the number of audited entities also increases the probability of more significant findings to which the government may want to respond and impose corrective remedies, this hypothesis has not been confirmed. However, in order to simplify the complex reality, the author has adopted an approximation to define the cost based on the number of audited entities and the duration of the audit. This finding would therefore lend itself to be in some way validated in the future, preferably with a regard to a longer period of time.

\section{CONCLUSION}

The results show that confirmed got only two of the three established hypotheses about the impact of audit findings on the media; however, these were based on stronger assumptions. The first is that in more than 200 audits that were initiated during the period 2010-2015, the relatively greater impact on the media had those audit actions in which at least one criminal notification was filed. The data provided by the Czech SAO and subsequently analysed by the author have also confirmed the hypothesis that no medium reported more audits performed by the Czech SAO than the Czech News Agency. However, in view of the media impact, the hypothesis that audits for which there were government-imposed remedial measures has not been proven to have a relatively greater media impact within the period under review.

The factor analysis findings have also pointed to the fact that for most (more than 80\%) of the years within the reviewed period there was confirmed the initially established hypothesis that notifications to the tax authorities were more frequent in audits that on average audited a longer period of time. This hypothesis was based on the assumption that the longer the audited period, the greater the probability of finding financial irregularities that had to be reported to the tax authorities. The results of factor analysis have further pointed to the fact that references to the Act on Accounting have in audit reports significantly decreased over the period under review. The hypothesis that the relative number of audits which focus on formal weaknesses and refer to the Act on Accounting has decreased over time has thus been confirmed. Also confirmed has been the hypothesis that the frequency of appeals against settlements of objections to audit protocols was more than $20 \%$ over the period under review.

34 This is evidenced by the established facts, when the number of appeals is close to $50 \%$ and in one year of the reviewed period even exceeds this value. 
Also revealed by the results of factor analysis were relatively large differences between the members in charge of the audit actions and tasked with drafting the audit reports based on the audit protocols. Confirmed therefore got the pre-established hypothesis that the direct impact of audit reports on the level of government-imposed corrective measures varied considerably depending on the individual SAO members; in this respect it also was not without interest that the most successful audit reports within the given review period had the member within whose course of the audit activity there were filed the most criminal notifications. However, in view of the financial aspect, the established hypothesis that over the course of the period under review, the audits in which were governmentimposed corrective measures were generally more costly was not confirmed.

Within the performed econometric analysis of the world which included available world countries there got confirmed the pre-set hypotheses that with the higher number of performed audit types and the Corruption Perceptions Index CPI, both the amount of the audited expenditures and the amount of the audited extra-budgetary funds under the SAI mandate increased. The findings with regard to the perceived level of corruption thus de facto follow up on the previous works in this area listed in the literature review and they are in comply with them (e.g. Gherai, Tara and Matica, 2016). Although these variables have a positive effect on the amount of audited expenditures, it has not been shown that other proposed variables (with the exception of the government expenditure relative to GDP and SAI transparency indicator in the case of audited budgetary expenditures) would increase the amount of expenditures audited under the SAIs' mandate. Conversely, the World Bank's Control of Corruption Indicator reduces both the amount of audited budgetary expenditures and the amount of extra-budgetary funds audited under the SAI mandate (for extra-budgetary funds, the amount of audited expenditures reduces also the Government Effectiveness Index). For the OECD sample of 22 countries for which data were available, there got confirmed the hypothesis that the amount of audited expenditures, including the amount of extra-budgetary funds under the SAI mandate, has increased with the number of performed audits types and the World Bank's Control of Corruption Indicator. While these variables have a positive impact on the amount of expenditures audited under the SAI mandate, it has not been proven that other suggested variables (with the exception of the SAI transparency indicator for budgetary expenditures) increase the amount of audited expenditures under the SAI mandate. Conversely, the way of dismissing the chief of SAI, respectively, the necessary final consent of the legislator or the judge before its dismissal reduces both the amount of audited budgetary expenditures and the amount of extra-budgetary funds audited under the SAI mandate (for the budgetary expenditures, the amount of audited expenditures gets decreased also by the Government Effectiveness Index).

\section{Acknowledgements}

The paper was prepared as one of the outputs of a research project of the Faculty of Finance and Accounting at the University of Economics „Economic and institutional aspects of public finance“ registered by the Internal Grant Agency of University of Economics, Prague under the registration number F1/7/2019.

\section{REFERENCES}

ADI, S. and DUTIL, P. 2018. Searching for strategy: Value for Money (VFM) audit choice in the new public management era. Canadian Public Administration, 61(1): 91-108.

AHONEN, P. and KOLJONEN, J. 2020. The contents of the National Audit Office of Finland performance audits, 2001-2016: An interpretive study with computational content analysis. Journal of Public Budgeting, Accounting \& Financial Management, 32(1): 49-66.

BLUME, L. and VOIGT, S. 2011. Does organizational design of supreme audit institutions matter? A cross-country assessment. European Journal of Political Economy, 27(2): 215-229.

BONOLLO, E. 2019. Measuring supreme audit institutions' outcomes: current literature and future insights. Public Money \& Management, 39(7): 468-477.

BRUSCA, I., MANES ROSSI, F. and AVERSANO, N. 2017. Accountability and Transparency to Fight against Corruption: An International Comparative Analysis. Journal of Comparative Policy Analysis: Research and Practice, 20(5): 486-504.

BUČEK, J. 2019. Have the Czech SAO's Audits Carried out in the Area of the State Budget Revenues Resulted in a Higher Number of Legislative Changes when Compared to the Audits in the Domain of the State Property Management? The NISPAcee Journal of Public Administration and Policy, 12(1): 9-41.

CARLITZ, R. et al. 2009. Budget transparency around the World: Results from the 2008 open budget survey. OECD Journal on Budgeting, 9(2): 19. 
CORDERY, C. and HAY, D. 2018. Supreme audit institutions and public value: Demonstrating relevance. Financial Accountability \& Management, 35(2): 128-142.

COMMITTEE ON AGRICUTURE OF THE CHAMBER OF DEPUTIES OF THE PARLIAMENT OF THE CZECH REPUBLIC. 2012. Resolution no. 103/2012.

COMMITTEE ON DEFENCE OF THE CHAMBER OF DEPUTIES OF THE PARLIAMENT OF THE CZECH REPUBLIC. 2014. Resolution no. 48/2014.

CONTROL COMMITTEE OF THE CHAMBER OF DEPUTIES OF THE PARLIAMENT OF THE CZECH REPUBLIC. 2011-2019. Resolutions on the audit conclusions of the Czech SAO between 2011-2019 (Resolutions no. 83/2011 - Resolution no. 150/2019). ${ }^{35}$

CZECH REPUBLIC. 1993. Act no. 166/1993 Coll., On the Supreme Audit Office, as amended [in Czech: Zákon č. 166/1993 Sb., Zákon o Nejvyšším kontrolním úřadu, ve znění pozdějších předpisů]. In: Sbírka zákonů České republiky.

CZECH REPUBLIC. 1992. Act No. 517/1992 Coll., Act of the Czech National Council on the Czech Press Office, as amended [in Czech: Zákon č. 517/1992 Sb., Zákon České národní rady o České tiskové kanceláři, ve znění pozdějších předpisů]. In: Sbírka zákonů České republiky.

CZECH REPUBLIC SUPREME AUDIT OFFICE. 2021. Annual reports 2010-2018. NKÚ: Czech Republic Supreme Audit Office [Online]. Available at: https://www.nku.cz/cz/publikace-a-dokumenty/vyrocnizprava/ [Accessed: 2019, November 10].

CZECH REPUBLIC SUPREME AUDIT OFFICE. 2019. Audit reports and information from Audit actions. NKÚ: Czech Republic Supreme Audit Office.

CZECH REPUBLIC SUPREME AUDIT OFFICE. 2021. EU reports 2010-2018. NKÚ: Czech Republic Supreme Audit Office. [Online]. Available at: https://www.nku.cz/cz/publikace-a-dokumenty/eureport/ [Accessed: 2019, November 25].

CZECH REPUBLIC SUPREME AUDIT OFFICE. 2021. Final accounts for the year 2010-2015 - Chapter 381. NKÚ: Czech Republic Supreme Audit Office. [Online]. Available at: https://www.nku.cz/cz/ publikace-a-dokumenty/zaverecny-ucet/ [Accessed: 2019, December 5].

CZECH REPUBLIC SUPREME AUDIT OFFICE. 2019. Internal SAO monitoring of media response. NKÚ: Czech Republic Supreme Audit Office.

FUKUDA-PARR, S., GUYER, P. and LAWSON-REMER, T. 2011. Does Budget Transparency Lead to Stronger Human Development Outcomes and Commitments to Economic and Social Rights? International Budget Partnerships Working Paper No. 4. Available at: http://dx.doi.org/10.2139/ssrn.2211584. [Accessed: 2019, August 10].

GHERAI, D.-S., TARA, I.-G. and MATICA, D.-E. 2016. The Supreme Audit Institution Can Control the Corruption or Not? Annals of Faculty of Economics, 1(2): 465-476.

GONZÁLEZ, B., LÓPEZ, A., GARCÍA, R. 2008. How do Supreme Audit Institutions Measure the Impact of their Work? In: JORGE, S. (Ed.). Implementing Reforms in Public Sector Accounting. Coimbra: Imprensa da Universidade de Coimbra.

GOVERNMENT OF THE CZECH REPUBLIC. 2010-2017. Government decisions - Resolutions on the audit conclusions of the Czech SAO between 2010-2017, Resolutions no. 857/2010 - Resolution no. 782/2017). ${ }^{36}$

GROENENDIJK, N. S. 2004. Assessing Member States' Management of EU Finance: An Empirical Analysis of the Annual Reports of the European Court of Auditors, 1996-2001. Public Administration, 82(3): 701-725.

35 Resolutions no. 83, 87, 97, 98, 104, 105/2011; Resolution no. 115,117, 118, 146, 153/2012; Resolution no. 171, 172, 176, 177, 183, 184/2013; Resolution no. 27, 34, 48, 51, 63, 64, 65, 67, 68, 69, 70, 73, 74/2014; Resolution no. 84, 85, 87, 95, 97, 98, 99, 100, 101, 102, 106, 107, 108, 109, 112, 113, 124, 125, 126, 127, 128, 144, 145, 146, 148, 161, 162/2015; Resolution no. $167,168,169,173,174,176,191,198,201,206,207,213,232,233 / 2016$; Resolution no. 239, 240, 241, 248, 249, 251, 263, 264, 275, 276, 282, 283, 284, 285/2017; Resolution no. 26, 27, 31, 39, 45, 48, 54, 61/2018; Resolution no. 68, 69, 70, 75, 76, 77, 79, 80, 81, 89, 96, 103, 114, 119, 123, 129, 148, 150/2019.

36 Resolutions no. 857/2010; Resolution no. 75, 76, 73, 74, 81, 104, 298, 303, 304, 307, 471, 472, 473, 474, 485/2011; Resolution no. 186, 187, 188, 189, 190, 191, 192, 206, 207, 208, 209, 210, 211, 212, 213, 225, 226, 227, 228, 229, 230, 231 , 232, 373, 489, 490, 491, 492, 493, 494, 495, 496, 497, 742, 743, 744, 745, 746, 747, 748, 749, 821, 822, 823, 824, 825, 826, 827, 828, 829, 889, 890, 891/2012; Resolution no. 21, 54, 55, 56, 179, 180, 181, 182, 183, 313, 314, 315, 316, 413, 414, 415, 416, 649, 650, 651, 652, 653, 654, 655, 764, 765, 766, 767, 768, 769, 770, 771, 772/2013; Resolution no. 3, 4, 5, 6, 7, 8, 16, 299, 300, 301, 302, 303, 304, 305, 306, 307, 410, 411, 412, 413, 414, 415, 416, 894, 895, 896, 897, 898, 899, 900, 1016, 1017, 1018, 1019, 1020, 1021, 1022, 1023, 1024, 1025, 1026, 1027/2014; Resolution no. 71, 72, 73, 74, 75, 305, 306, 307, 308, 570, 687, 688, 689, 690, 691, 692, 996, 997, 998, 999, 1000, 1001, 1002, 1003, 1004, 1005/2015; Resolution no. 103, 104, 105, 106, 107, 108, 154, 155, 156, 157, 158, 159, 160, 161, 296, 297, 298, 299, 439, 440, 441, 442, 443, 444, 770, 771, 772, 773, 774, 775, 776, 777, 982, 983, 984, 985, 986, 987, 988, 989, 990, 991, 1077, 1078, 1079, 1080, 1081, 1082, 1083, 1084, 1085, 1086, 1094/2016; Resolution no. 230, 231, 233, 234, 782/2017. 
HAPPER, C. and PHILO, G. 2013. The Role of the Media in the Construction of Public Belief and Social Change. Journal of Social and Political Psychology, 1(1): 321-336.

HARRISON, T. M. and SAYOGO, D. S. 2014. Transparency, participation, and accountability practices in open government: A comparative study. Government Information Quarterly, 31(4): 513-525.

INTOSAI GENERAL SECRETARIAT. 1977. The Lima Declaration of Guidelines on Auditing Precepts. IX INTOSAI in Lima. [Online]. Available at: https://www.nku.cz/assets/about-us/status-and-powers/ lima-declaration-mexico-declaration.pdf [Accessed: 2019, December 12].

JOHNSEN, A. 2019. Public sector audit in contemporary society: A short review and introduction. Financial Accountability \& Management, 35(2): 121-127.

JOHNSEN, Å., REICHBORN-KJENNERUD, K., CARRINGTON, T., JEPPESEN, K., TARO, K. and VAKKURI, J. 2019. Supreme audit institutions in a high-impact context: A comparative analysis of performance audit in four Nordic countries. Financial Accountability \& Management, 35(2): 158-181.

KAUFMANN, D., AART, K. and MASSIMO, M. 2010. The Worldwide Governance Indicators: Methodology and Analytical Issues. World Bank Policy Research Working Paper No. 5430. The World Bank.

LONSDALE, J. 2000. Developments in Value-For-Money Audit Methods: Impacts and Implications. International Review of Administrative Sciences, 66(1): 73-89.

LONSDALE, J. 1999. "Impacts.” In: POLLITT, C., GIRRE, X., LONSDALE, J., MUL, R., SUMMA, H. and WAERNESS, M. (Eds.). Performance or Compliance? Performance Audit and Public Management in Five Countries. Oxford: Oxford University Press, pp. 171-193.

MIR, M., FAN, H. and MACLEAN, I. 2017. Public sector audit in the absence of political competition. Managerial Auditing Journal, 32(9): 899-923.

NEMEC, J., OCHRANA, F., PAVEL, J. and ŠAGÁT, V. 2010. Control in Public Administration [in Czech: Kontrola ve veřejné správè]. $1^{\text {st }}$ Edition. Prague: Wolters Kluwer ČR.

OPEN BUDGET SURVEY. 2017. Questionnaire and Guidelines, Data. International Budget Partnership. [Online]. Available at: https://www.internationalbudget.org/publications/open-budget-survey-2017/ [Accessed: 2019, September 5].

POLLITT, C. 2003. Performance Audit in Western Europe: Trends and Choices. Critical Perspectives on Accounting, 14(1-2): 157-170.

POLLITT, C., XAVIER, G., LONSDALE, J., MUL, R., SUMMA, H. and WAERNESS, M. 1999. Performance or Compliance? Performance Audit and Public Management in Five Countries. Oxford: Oxford University Press.

POLLITT, C. and SUMMA, H. 1997. Reflexive Watchdogs? How Supreme Audit Institutions Account for themselves. Public Administration, 75(2): 313-336.

RAMKUMAR, V. 2009. The State of Budget Transparency Worldwide. International Journal of Government Financial Management, 9(2): 1-14.

REICHBORN-KJENNERUD, K., CARRINGTON, T., JEPPESEN, K. and TARO, K. 2018. A New Organisation of Public Administration: From Internal to External Control. In: Bureaucracy and Society in Transition. Comparative Social Research, Vol. 33. Bingley: Emerald Publishing Limited, pp. 225-243.

REICHBORN-KJENNERUD, K., GONZÁLEZ-DÍAZ, B., BRACCI, E., CARRINGTON, T., HATHAWAY, J., JEPPESEN, K. and STECCOLINI, I. 2019. SAIs Work Against Corruption In Scandinavian, South-European And African Countries: An Institutional Analysis. The British Accounting Review, 51(5): 100842.

REICHBORN-KJENNERUD, K. and JOHNSEN, A. 2015. Performance Audits and Supreme Audit Institutions' Impact on Public Administration: The Case of the Office of the Auditor General in Norway. Administration \& Society, 50(10): 1422-1446.

RENZIO, P. D. and MASUD, H. 2011. Measuring and Promoting Budget Transparency: The Open Budget Index as a Research and Advocacy Tool. Governance, An International Journal of Policy, Administration, and Institutions, 24(3): 607-616.

RÍOS, A.-M., BASTIDA, F. and BENITO, B. 2016. Budget Transparency and Legislative Budgetary Oversight: An International Approach. The American Review of Public Administration, 46(5): 546-568.

SEDMIHRADSKÁ, L., HAAS, J. 2012. Budget transparency and fiscal performance: Do open budgets matter? MPRA Paper No. 42260. Available at: https://mpra.ub.uni-muenchen.de/42260/. [Accessed: 2019, December 30].

SEIFERT, J., CARLITZ, R. and MONDO, E. 2013. The Open Budget Index (OBI) as a Comparative Statistical Tool. Journal of Comparative Policy Analysis: Research and Practice, 15(1): 87-101.

STAŠOVÁ, L. H. 2019. The scope of control of the supreme audit office in the Slovak Republic and in the other Visegrad Four countries. Society and Economy, 41(2): 245-262.

SVÄRDSTEN, F. 2019. The 'front stage' of substance auditing: A study of how substance auditing is presented in performance audit reports. Financial Accountability \& Management, 35(2): 199-211. 
TIRON TUDOR, A. and MOLDOVAN-ROMAIN, R. 2019. What influences disclosure choice in EU Supreme Audit Institutions' performance audit annual reports? Project: Public sector accounting. ACCA Think Ahead.

TRANSPARENCY INTERNATIONAL. 2018. Corruption Perceptions Index 2017. Transparency International Report.

UNION OF PUBLISHERS AND ASSOCIATION OF MEDIA AGENCIES. 2016. Readership research MEDIA PROJECT [in Czech: Výzkum čtenosti tisku MEDIA PROJEKT]. Unie Vydavatelů. [Online]. Available at: http://www.unievydavatelu.cz/cs/unie_vydavatelu/medialni_data/vyzkum_ctenosti [Accessed: 2019, December 20].

VAN ACKER, W. and BOUCKAERT, G. 2018. The impact of supreme audit institutions and ombudsmen in Belgium and The Netherlands. Financial Accountability \& Management, 35(1): 55-71.

VAN ZYL, A., RAMKUMAR, V. and DE RENZIO, P. 2009. Responding to challenges of Supreme Audit Instituions: Can legislatures and civil society help? U4 ISSUE 2009:1. Anti-Corruption Resource Centre. Available at: https://www.cmi.no/publications/file/3287-responding-to-the-challenges-of-supremeaudit.pdf [Accessed: 2019, October 15].

WORLD BANK. 2019. Data. World Bank. [Online]. Available at: https://data.worldbank.org0/ [Accessed: 2019, September 10].

YETANO, A., TORRES, L. and CASTILLEJOS-SUASTEGUI, B. 2019. Are Latin American performance audits leading to changes? International Journal of Auditing, 23(3): 444-456.

ZUCCOLOTTO, R. and TEIXEIRA, M. A. C. 2014. Budgetary Transparency and Democracy: The Effectiveness of Control Institutions. International Business Research, 7(6): 83-96.

Contact information

Jan Buček: xbucj00@vse.cz (corresponding author) 